\title{
Sustainable forest management in Poland - theory and practice
}

\author{
Hanna Kruk ${ }^{1} \bowtie$, Bożena Kornatowska ${ }^{2}$ \\ ${ }^{1}$ Gdynia Maritime University, Faculty of Entrepreneurship and Quality Science, Department of Economics and \\ Management, Morska 81-87, 81-225 Gdynia, Poland, phone: +48 58 6901544, e-mail: h.kruk@wpit.am.gdynia.pl \\ ${ }^{2}$ Institute of Environmental Protection-NRI, Department of Nature and Landscape Conservation, Kolektorska 4, \\ 01-692 Warsaw, Poland
}

\section{Abstract}

The conception of sustainable development has been implemented into practice in numerous economic sectors, including forestry. Forest ecosystems are extremely important in the global ecological system, therefore maintenance and appropriate management of forest resources according to sustainable development principles have engaged a great deal of attention. The concept of sustainable forest management (SFM) encompasses three dimensions: ecological, economic and social. A powerful tool to promote SFM are criteria and indicators. The aim of the article was evaluation of SFM in Poland, using one of the methods proposed by the Food and Agriculture Organization (FAO). According to data available, Polish forestry has a number of advantages: Poland has avoided the problem of deforestation, forest area has been permanently increasing, there has been observed improvement of forest health and vitality as well as a significant share of forests has carried out protective functions with no impact on timber production. Poland's model of SFM is an adaptive process of balancing the ever-changing set of economic, environmental and social expectations. Such a complicated undertaking requires constant assessing and adjusting forest practices, in response to new circumstances, scientific advances and societal input.

\section{KeY WORDS}

sustainable forest management, forestry, forest functions, Poland

\section{INTRODUCTION}

The concept of sustainable development (Keiner 2004) is taken into consideration in numerous economy sectors, with forestry being no exception. Forests are extremely important in the ecology of the Earth. They produce multiple environmental benefits including biodiversity conservation, carbon sequestration, and protection against desertification. Appropriately managed forests can enhance the provision of wood and nonwood forest products for millions of people. At the same time, forest ecosystems play a key role in mitigation of climate change effects.

Sustainable forest management (SFM) is the management of forests according to the principles of sustainable development. The most far and wide respected definition of sustainable development was presented in "The World Commission on the Environment and 
Development (the Brundtland Commission) Report on Our Common Future in 1987": "Development that meets the needs of the present without compromising the ability of future generations to meet their own needs" (Keiner 2004). Five years after publication of the Brundtland Report, the UN General Assembly convened the United Nations Conference on Environment and Development (UNCED) with the objectives built upon the achievements of the Report so as to respond to environmental problems and to agree major treaties on biodiversity, climate change and forest management (Report of the UN Conference on environment and development 1992).

There is no globally agreed-on definition of sustainable forest management (SFM). Gusstavson et al. 2005 (Panagopoulos 2009) defined SFM as "long-term management of complex habitats in order to perform their multiple functions into the future". Appropriate forest management is crucial for maintenance of forest resources for present and future generations. Forest management encompasses a broad scope of issues, namely: exploiting of wood and non-wood forest products at the same time avoiding deforestation, keeping forest ecosystems in good conditions, preserving biodiversity, protecting rare endangered species and other values of nature including landscape, improving welfare of local societies as well as enhancing cultural values and tourism. The concept of SFM includes ecological, economic and social aspects. The ecological aspect encompasses not only inner- and inter-ecosystem dependences but also equal treatment of all values which forests provide. The economic dimension concerns improving welfare and the use of forest products. The latter denotes that needs of various groups of interest like local societies, hunters, farmers, tourists, landowners should be taken into account during planning forest management strategies (Szaro et al. 2000). Managing forests with and for the people means listening to and learning from them. The social aspect of SFM encompasses both technical and political dimensions and has been the major challenge in forest management for the last decades. Other concepts related to SFM include among others nature-oriented silviculture (Meyerhof et al. 2009) and the idea of functional areas in forestry (Drozdowski 2008).

The goals for SFM elaborated at a global level by the United Nations (United Nations Global Objectives to Forests towards 2015) comprise the following (Forestry in the EU and the world - a statistical portrait 2011):

- reversing deforestation, protecting forests and preventing forest degradation,

- improving the use of economic, social and environmental benefits from forests,

- enhancing the areas of protected forests and other areas of SFM (aiming at better proportion between productive forests and those sustainably managed),

- strengthening official assistance for SFM (including financial support).

The main aim of this paper was to present essential information on the state of forests in Poland evaluated in the context of their sustainable management. The analyses were carried out against the background of forest situation in the European Union. The evaluation of the latter was possible only partially due to the lack of relevant data at a European level or its inaccessibility.

\section{SUSTAinABle forest MANAGEMENT IN EUROPE}

Awareness on the vital role that forests play in socioeconomic development and multiplicity of forest values as well as knowledge about complex relationships within forest ecosystems has contributed to reshaping timber forest management into sustainable management of forests worldwide. Broadly accepted definition of sustainable forest management (SFM) at a PanEuropean level was adopted at the Second Ministerial Conference on the Protection of Forests in Europe (MCPFE - known as FOREST EUROPE, re-named in 2009) convened in Helsinki, Finland in 1993. According to MCPFE sustainable forest management "means the stewardship and use of forests and forest lands in such a way, and at a rate, that maintains their biodiversity, productivity, regeneration capacity, vitality and their potential to fulfill, now and in the future, relevant ecological, economic and social functions, at local, national, and global levels, and that does not cause damage to other ecosystems" (Forestry in the EU and the world - a statistical portrait 2011; Baycheva at al. 2013). A definition of SFM was developed by MCPFE (FOREST EUROPE) has since been adopted by the European Union as well as Food and Agriculture Organization 
(FAO). In Poland, SFM definition provided in the Act on Forests (art. 6, § 1a, http://isap.sejm.gov.pl) is fully compliant with the one established by MCPFE.

According to the three dimensions embraced in sustainable development concept, the principal elements of SFM in Europe include:

- ecological dimension - maintaining and increasing biological diversity of forests, sustaining natural processes, preserving the most precious elements of nature;

- economic dimension - treating forests as a source of numerous product types (including timber) and work-place provider (of high importance in neglected regions), manufacturing based on forest products, monitoring (especially tree healthiness), conducting scientific research towards forest management enabling maintenance of their capacity to continuously restore;

- social dimension - improving the quality of life including poverty reduction, strengthening social participation, empowerment and activity of local societies, enhancing ecological awareness, fostering co-operation among forest owners.

The Forestry Strategy for the European Union adopted by the European Council in 1998 encompasses among others: supporting sustainable forest management in connection with multifunctional role of forests, respecting the principle of subsidiarity, accenting the role of the SFM for maintaining biodiversity and nature conservation, promoting timber and non-timber products used as a part of environmentally friendly production, enhancing cooperation and participation of stakeholders (private and public), emphasizing contribution of the forestry sector to national economy and the quality of life (European Council 1998). Milestones for European forestry were established in 2006 by the EU Forest Action Plan. Principal foundations of the document include, among others, enhancing competitiveness of the forestry sector, amending governance of European forests, ameliorating coherence and coordination of the EU's cross-country forest policy, protecting forest ecosystems, improving the health condition of forests, bettering the quality of life and fostering communication and coordination (COM(2006) 302 final).

In 2013, the new EU Forest strategy was elaborated. The main principles of SFM were identified as follows (COM(2013) 659 final):
- sustainable forest management and the multifunctional role of forests, delivering multiple goods and services in a balanced way and ensuring forest protection,

- resource efficiency, optimising the contribution of forests and the forest sector to rural development, growth and job creation,

- global forest responsibility, promoting sustainable production and consumption of forest products.

\section{AsSessment METHOdS AND DATA SOURCES}

The level of sustainability is measured with numerous indicators in various arrangements. Their lists are usually extensive, that is why they receive strong criticism from many authors. One must bear in mind that not all elements, values and services (especially environmental and social aspects) may be expressed by quantitative measures. Therefore, the estimates are sometimes ambiguous and the results - not always credible and objective (Bartelmus 2003). Nevertheless, a variety of indicators for SFM has been applied. In general, two groups of tools are distinguished: criteria and indicators that allow to implement consistently the principles of sustainable development into forestry and receive information on SFM achievements. The term criterion reflects the conditions of the process used for SFM assessment, whereas indicators allow measurement of given criterions (Wijewardana 2008).

The complex tool for assessment was prepared by MCPFE. The process has developed a pan-European set of criteria and indicators (C\&I), which consists of 6 criteria and 35 quantitative indicators (describing the forest status and changes) as well as 17 qualitative indicators (describing national forest policies, institutions and instruments towards SFM). C\&I set has served as the basis for State of Europe's Forests assessments in 2003, 2007 and 2011, and provided the foundation for regional and national policy formulation, analysis and monitoring. Criteria embrace the following aspects: enhancement of forests and their role in the global carbon cycle (C1), maintenance of forest ecosystem health and vitality (C2), maintenance and encouragement of productive functions of forests (C3), maintenance, conservation and appropriate enhancement of biological diversity in forest ecosystems (C4), maintenance and appropriate 
enhancement of protective functions in forest management (notably soil and water) (C5), and enhancement of other forests socio-economic functions (C6) (Baycheva at al. 2013).

Another comprehensive means for forest evaluation was proposed by FAO (Global Forest Resources Assessment 2005, 2010). Seven principal groups of indicators were separated, namely (Global Forest... 2010):

- the extent of forest resource [area of forests and other wooded land (ha), growing stock of forests $\left(\mathrm{m}^{3}\right)$ and carbon stock per hectare in forest biomass (tons/ha)];

- biological diversity [area of primary forests, area of forests with major protective functions (designated for conservation of biodiversity) and total forest area alongside with plantations (all measured in ha)];

- forest health and vitality [area of forests affected by fire and forest cover damaged by insects, fungus diseases and other factors (quantified in ha per year)],

- productive functions of forest resources [area of forests with productive primary function (ha), area of productive forest plantations (ha), commercial growing stock $\left(\mathrm{m}^{3}\right)$, total wood removals $\left(\mathrm{m}^{3} /\right.$ year) and total non-wood forest products (NWFP) removals (tons/year)];

- protective functions of forest resources [area of protected forests (ha) and area of protective forest plantations (ha)];

- socio-economic functions [value of total timber products and non-timber products (US dollars/year), employment (number of workers in a given year), area of forests privately owned (ha) and area of forests with social services as a dominant function (ha)];

- legal, policy and institutional framework [policy, forest law forest national programme, institutional structure of forestry and human resources (staff, share of highly graduated in forestry, etc.)].

The tool developed by FAO allows for complex assessments of SFM implementation. However, some economic and social aspects of SFM are taken into consideration only in a limited scope, e.g. the quality of life, preservation of cultural heritage, tradition related with forests and hunting, social participation and empowerment, relationship between forests ownership and forests conditions are not included. Besides, in case of some categories, data are not commonly available.
Therefore, for the purpose of this paper the main criteria were modified.

- In order to evaluate the state of forests in Poland and a level of their sustainability, the following categories were selected and used in further analyses as criteria of SFM achievements:

- forest area, tree species composition and changes in them - total forest area, forests area per capita, rate of afforestation (or deforestation), share of coniferous and broadleaved trees;

- state of health in forests and its changes - threats posed by fungi, insects, animals, and damage due to air pollution (defoliation);

- forest production, main products and services - wood and non-wood products, eco-certification;

- preserving biodiversity - forest age structure, habitat constitution and species composition (tree species and forest type habitat suitability), potential and existent threats to biodiversity (monotypic forests, neophytisation, pinetisation) and forest protection (protective forests, protected areas in forests and NATURA 2000 sites);

- forests ownership and its influence on forest estate and management;

- social functions of forests - utilization by different groups of interest (recreation, tourism, hunting), education (including Promotional Forest Complexes - PFC, arboreta), preserving cultural heritage.

The analyses based on the above approach were performed with the use of statistical data and publications available from Eurostat, FAO, the Central Statistical Office of Poland (GUS), the State Forests National Forest Holding and other institutions. There were found some discrepancies among the data obtained, most probably due to different methodologies used by data providers. The year 2010 was assumed as the reference in comparisons carried out. Depending on data availability the changes were examined between 2010 and previous years (2000 or 2005 or even earlier). In a few cases there were data available only for 2005 .

The comparisons between the state of Polish and European forests were also conducted. As some statistical data concerning the European Union (EU-27) were not available, international comparisons were not performed for all the aforementioned categories (e.g. in point 4 - preserving biodiversity). 


\section{State of Poland's forests}

Poland is one of the European countries with the biggest forest area (app. 9, 4 million ha, Global Forest... 2010). The majority of Poland's forests belong to the State Treasury, on behalf of which state owned forests are managed by the National Forest Holding "State Forests" (State Forests) headed by the General Director. The General Directorate is in charge of 17 Regional Directorates with altogether 431 forest districts divided into Forest-ranges (The State Forests in figures 2011). Poland's forest ownership structure is summarized below (tab. 1).

Tab. 1. Forest ownership structure in Poland in 2010

\begin{tabular}{|c|c|c|c|c|c|}
\hline \multirow[b]{2}{*}{ Share } & \multicolumn{4}{|c|}{ Public forests } & \multirow[b]{2}{*}{ 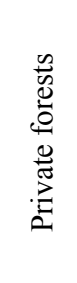 } \\
\hline & 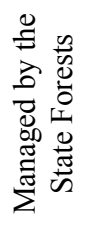 & 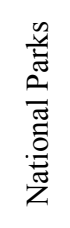 & 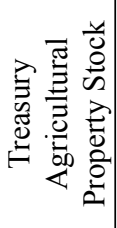 & 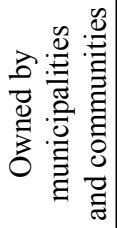 & \\
\hline thousands of ha & 7072 & 184 & 36 & 84 & 1686 \\
\hline$\%$ & 78.04 & 2.03 & 0.40 & 0.93 & 18.60 \\
\hline
\end{tabular}

Source: GUS 2011b.

Since UNCED held in Rio de Janeiro in 1992, new legislation concerning sustainable forestry in Poland has been adopted, including the Forest Act (1991), the National Forestry Policy (1997), Regulations on Promotional Forest Complexes (1994, 1999, 2002), Regulations by the General Director of State Forests: No. 11 (1995) and No. 11a (1999) on ecological basis of forest management; the Instruction for preparation of the Nature Protection Programme as an integrated part of the Forest Management Plan for each forest district (1996), the Instruction of Forest Management (1994) and so on. According to the provisions in the 1995 Act on the Protection of Agricultural and Forest Lands, the protection of forest lands is based "upon (...) prevention of degradation or devastation processes in forest land and of damage in tree stands (...)".

\section{Forest area, tree species composition and their changes}

In Poland, forests and wood areas cover around 29.9\% of land area, i.e. less than the average value for 27 countries of the European Union (EU-27) (Eurostat Newsre- lease 85 2011). Basic data concerning the total area of forested land in Poland and that in the EU are presented in table 2.

Tab. 2. Forests areas and their changes in Poland and EU in 2010 (average for 27 countries)

\begin{tabular}{|c|c|c|c|}
\hline $\begin{array}{l}\stackrel{\Xi}{\Xi} \\
ٍ \\
ٍ\end{array}$ & 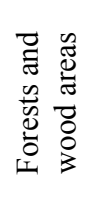 & 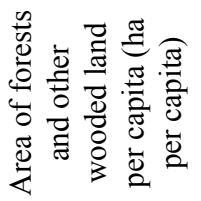 & 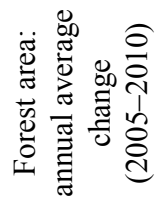 \\
\hline EU-27 & $41 \%$ & 0,35 & $0,32 \%$ \\
\hline Poland & $29,9 \%$ & 0,24 & $0,30 \%$ \\
\hline
\end{tabular}

Source: Eurostat Newsrelease 85, 2011; Forestry in the EU and the world - a statistical portrait 2011; GUS 2011b.

The data presented demonstrate that Poland has avoided the problem of deforestation, however, the share of forests and wood areas is below the EU's average. Poland's forest cover is planned to be consequently increased. The National Programme of Increasing Forest Cover (NPIFC, revised in 2002) is a key element of the Polish strategy on improving the country's space structure and developing rural areas relative to implementation of sustainable, balanced and multi-functional forest management. It embraces the principle to reach $30 \%$ forests cover in 2020 and 33\% in 2050 . However, the pace of increasing forests' extent in Poland has been slackening. In 2006-2010 only about $1 / 3$ of planned afforestation was realized $-36 \%$ within the state owned forests and $31 \%$ within private and community owned forests, whereas in the years 2001-2005, $81 \%$ of planned afforestation was achieved $(96 \%$ and $70 \%$, respectively).

Assuring appropriate tree species composition and percentage share of tree stands in conformity with a type of a given forest site poses further important questions in performance of desirable and appropriate forest management. The changes in tree species composition (percentage shares) and age classes in Poland's forests in the years 1945-2010 are presented in table 3 .

Generally, in the forests managed by the State Forests, the share of coniferous trees (especially pine) in species composition is higher than that in privately owned (GUS 2010). The pine (Pinus sylvestris) is the most widespread species preferred by the timber industry. The share of broadleaved species has been rising 
constantly since the year 1945 . However, the appraisal of species structure of forests in Poland with regard to forest site types (fig. 1) indicates that the share of broadleaves trees is lower than potentially possible as well as that a part of tree stands grows in the conditions not consistent with their favourite habitats. Actions leading to correction of stands' structure have been undertaken during afforestation/reforestiation activities, nevertheless the composition of elder tree stands cannot be altered promptly and without difficulty.

Tab. 3. Species and age composition of forests in Poland

\begin{tabular}{|l|c|c|c|}
\hline \multicolumn{1}{|c|}{ Year } & 1945 & 1997 & $\begin{array}{c}2006- \\
-2010 *\end{array}$ \\
\hline \multicolumn{3}{|c|}{ Species structure of tree stands } \\
\hline Coniferous trees & $87.0 \%$ & $77.3 \%$ & $70.7 \%$ \\
\hline Deciduous trees & $13.0 \%$ & $22.7 \%$ & $29.3 \%$ \\
\hline \multicolumn{3}{|c|}{ Age class of tree stand } \\
\hline $\begin{array}{l}\text { I (age 1-20 years and } \\
\text { restocking class }\end{array}$ & $23.2 \%$ & $17.2 \%$ & $14.0 \%$ \\
\hline II (21-40 years) & $22.8 \%$ & $24.6 \%$ & $16.0 \%$ \\
\hline III (41-60 years) & $18.5 \%$ & $21.8 \%$ & $27.1 \%$ \\
\hline IV (61-80 years) & $13.1 \%$ & $17.6 \%$ & $18.3 \%$ \\
\hline V and higher (over 81 years) & $14.3 \%$ & $17.0 \%$ & $20.9 \%$ \\
\hline $\begin{array}{l}\text { Blanks, feeling sites and } \\
\text { irregularly stocked open stands }\end{array}$ & $8.1 \%$ & $1.8 \%$ & $3.7 \%$ \\
\hline
\end{tabular}

${ }^{*}$ Due to changes in research methods, these data are not fully of the same kind with those from previous years.

Source: GUS 2009, GUS 2011b.

In Poland, there also exist forest plantations of fastgrowing tree species, mainly Populus sp. and Larix decidua (app. $87 \%$ of all plantations). However, the share of such plantations in the total forest area is not considerable (Kozioł and Matras 2011).

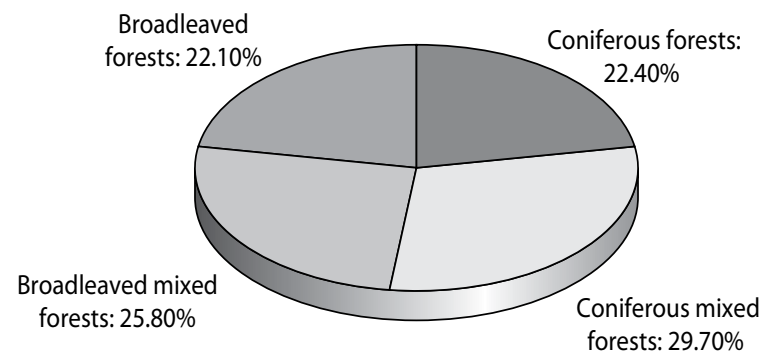

Fig. 1. Share of coniferous and broadleaved stands in Polish forests
Source: GUS 2011b.

Another issue concerning forest stands is their age and its changes (tab. 3). The average age of all tree stands in Poland is app. 56 years (State Forests managed -57 years and privately owned -46 ). The age structure has been continually improved. Even though designated tree stands are harvested and new areas are continually afforested, all things considered - the share of older tree stands in the total forest area has been increasing for the last decades.

\section{State of health in the forests and its changes}

Health and vitality of forests may be assessed in line with the following criteria: defoliation (tab. 4) as well as leaf discolouration, diseases caused by fungi and insects, damages caused by animals and forest fires (tab. 5).

Tab. 4. Forest tress damaged by defoliation in Polish forests when compared with average within the EU

\begin{tabular}{|c|c|c|}
\hline Defoliation & Poland & EU-27 \\
\hline Year 2000 & in classes $2-4: 32 \%$ & in classes $2-4: 21.7 \%$ \\
\hline Year 2010 & $\begin{array}{l}\text { in classes } 2-4: 20.7 \% \\
\text { adequately: } \\
\text { in class } 0: 21.0 \%, \\
\text { in class } 1: 58.3 \%, \\
\text { in class } 2: 19.6 \% \text { and } \\
\text { in classes } 3-4: 1.1 \%\end{array}$ & $\begin{array}{l}\text { in classes } 2-4: 22.6 \% \\
\text { adequately: } \\
\text { in class } 0: 32.3 \% \text {, in } \\
\text { class } 1: 45 \%, \\
\text { in class } 2: 20.1 \% \text { and } \\
\text { in classes } 3-4: 2.5 \%\end{array}$ \\
\hline
\end{tabular}

Source: GUS 2011b, Eurostat.

Healthiness of trees is usually defined by the intensity of defoliation and a level of leaf or needle decolouration, and these illustrate damages due to air pollution (6.6\% of Poland's forests are considered damaged by industry, GUS 2011b). Five classes of defoliation have been conventionally used in the EU including Poland: from class 0 (no defoliation) to class 4 (dead trees). The same classification has been also used to assess degradation of forests (GUS 2011b). Generally, the results of tree health evaluations in Polish forests carried out consistent with the abovementioned method on selected plots (the socalled fixed observation areas) in the years 2000-2010, allow to draw the following conclusions with regard to forest tree defoliation (GUS 2011b; GUS 2008a; Forestry in the EU and the world - a statistical portrait 2011):

- there are no significant differences between health conditions of coniferous and broadleaved trees in Poland; 
- comparison of spatial diversity of average defoliation shows, that forests in northern and west-northern parts of the country indicate the best conditions (average defoliation in 2010 for all these regions was below 20\%);

- average defoliation does not depend on forest ownership - the percentage of trees suffering from the process is alike in public and private forests;

- the percentage of trees with severe defoliation in Poland is below the average in the EU;

- the results of damage evaluation in selected tree species (more than 20-year-old specimens) show that both for coniferous and broadleaved trees the problem exists in very small fragments of forests: only $0.99 \%$ of coniferous trees and $1.63 \%$ broadleaved trees belong to damage classes 3-4.

Taking the above into account, healthiness of Polish forests measured by defoliation criterion can be considered as reasonably good and continually improving.

Tab. 5. Health of forests in Poland measured by means of other criteria

\begin{tabular}{|c|c|c|}
\hline Question & Year 2000 & Year 2010 \\
\hline Discolouration & $\begin{array}{l}98.67 \% \text { of forests } \\
\text { with no changes; } \\
0.47 \% \text { of forests } \\
\text { in classes } 3-4 \\
\text { (significant } \\
\text { damage) }\end{array}$ & $\begin{array}{c}92.27 \% \text { with no } \\
\text { changes; } \\
0.28 \% \text { in class } \\
3-4 \text { (significant } \\
\text { damage) }\end{array}$ \\
\hline $\begin{array}{l}\text { Forest area protected } \\
\text { against insects }\end{array}$ & 169,562 ha & 12,825 ha \\
\hline $\begin{array}{l}\text { Forest area protected } \\
\text { against parasitic } \\
\text { fungal diseases }\end{array}$ & 93,533 ha & 23,747 ha \\
\hline $\begin{array}{l}\text { Forest area protected } \\
\text { against damage } \\
\text { caused by game } \\
\text { animals }\end{array}$ & 127,574 ha & 79,842 ha \\
\hline $\begin{array}{l}\text { Total forest area } \\
\text { endangered by fungi } \\
\text { diseases }\end{array}$ & $\begin{array}{c}546,863 \text { ha } \\
(7.9 \% \text { of total } \\
\text { forest area) }\end{array}$ & $\begin{array}{c}384,033 \text { ha } \\
(5.5 \% \text { of total } \\
\text { forest area })\end{array}$ \\
\hline $\begin{array}{l}\text { Number of forest } \\
\text { fires }\end{array}$ & 12,428 & 4,681 \\
\hline $\begin{array}{l}\text { Area of burned } \\
\text { forest }\end{array}$ & 7,013 ha & 2,126 ha \\
\hline $\begin{array}{l}\text { Reconstructed forest } \\
\text { area }\end{array}$ & 8,650 ha & 10,641 ha \\
\hline
\end{tabular}

Source: GUS 2008b, GUS 2011b.
The analysis based on other criteria on forest health conditions $^{1}$ (tab. 5) allows the following conclusions concerning Poland's forests:

- the area of forests protected against harms caused by insects, fungal diseases and game animals has been continuously decreasing;

- emission of air pollutants and natural disasters cause the necessity of tree stand restoration; many weather anomalies have been recorded in the last decade and probably due to their impact there increased the area of reconstructed forests;

- the number of fires and the area of forests affected by them have decreased ${ }^{2}$; the main reasons for fires in forests are arsons and carelessness (GUS 2012).

Taking the above into account, one can state that for the last decade, the state of health in Polish forests has been improved.

\section{Forestry, production, main forest products and services}

Timber is the main forest product. Poland's forests remain one of the best stocked in Europe. In Polish conditions, average resources of wood in 2010 equaled 219 $\mathrm{m}^{3} / \mathrm{ha}$, whereas the corresponding figure for Europe (without Russian Federation) was $156 \mathrm{~m}^{3} / \mathrm{ha}$. Timber falls into three main groups with regard to the thickness of removed wood: merchantable (large) timber, lumber (slash) and stump wood (GUS 2011b). The production of timber in Poland is characterised by a rising tendency. In 2000, 27,659 thousand $\mathrm{m}^{3}$ of timber was harvested, in $2010: 34,567$ th. $\mathrm{m}^{3}\left(0.88 \mathrm{~m}^{3}\right.$ per capita $)$, and this was $1.04 \%$ of global share (GUS 2012) and $9.28 \%$ of the EU-27 production (State of Europe's Forests 2011). The main group of timber was large timber $\left(35,468\right.$ th. $\left.\mathrm{m}^{3}\right)$, then slash (about 1,899 th. $\mathrm{m}^{3}$ ) and stump wood ( 0.1 th. $\mathrm{m}^{3}$ ) (GUS 2011b). In the same year, Poland took fifth place in the EU countries with reference to roundwood removals (Eurostat data). With regard to the species structure of tree stands in Poland, harvesting of coniferous trees is predominant (Forestry in the EU and the world - a statistical portrait 2011).

\footnotetext{
${ }^{1}$ Relevant data for the EU for the year 2010 are not available.

${ }^{2}$ Numbers of forest fires and burned areas in Poland are lower when compared to the Mediterranean countries but they considerably exceed those in neighbouring countries, e.g., Germany (GUS 2011b).
} 
It is assumed that timber harvesting in Poland lies within the limits of securing ecosystems' ability to selfrestoration and sustainability, and is performed without harming their capacity to sustain equilibrium along with maintaining a constant increase of forest area (Bernadzki 2006). According to the Report on the forests conditions in Poland 2010, forest resources (measured by log volume) have a rising tendency. However, in the case of the State Forests, about $18 \%$ of wood removals have come from tending cuts and those connected with the necessity of improvement felling after disasters so as to keep proper sanitary conditions of forests. It is also important to note that rising tendency of timber harvesting is related to improving the gross timber resources per hectare of the age group III (41-60 years) and older (Forests in Poland 2011).

Non-wood products of forest, such as forest fruits (mainly berries ${ }^{3}$ ), mushrooms $s^{4}$ and game animals ${ }^{5}$ have been gaining more and more importance. The Polish Central Statistical Office provides no more than figures on fruits and mushrooms procured for specialised enterprises. Due to free public access to Poland's forests, everyone has a right to collect forest fruits and mushrooms without limits (only protected species are restricted). Hence, the volume of forest fruits and mushrooms harvested is impossible to estimate, likewise the volume of collected herbs ${ }^{6}$.

Proper forests management including wood harvesting is subject to eco-certification. According to the data available at the State Forests' web page and those at web pages of Regional Directorates of the State Forests, in 2010, 15 out of all 17 regional directorates hold the Forest Stewardship Council (FSC) certificates. In case of the Regional Directorate of the State Forests in Bialystok, FSC certificates were awarded to 28 out of 31 forests districts?

${ }^{3}$ In 2005, 19,138 tons of fruits were purchased, in 2010: 8,374 tons (GUS 2011b).

${ }^{4}$ In 20054,186 tons of mushrooms (various species) were purchased and in 2010: 4,467 tons (GUS 2011b).

${ }^{5}$ In 2010, the procurement of game was 9,899 tons; the most numerous were wild boars and deer (GUS 2011b).

${ }^{6}$ Data not available.

${ }^{7}$ In 2011, the Regional Directorates started applying for yet other certificate - PEFC (the Programme for the Endorsement of Forest Certification). Now, all Directorates have been already awarded PEFC certificates.
Harmful activities in Polish forests comprise unlawful use of forests, poaching, theft and property destruction and also timber theft (GUS 2011b). Although, in general, the number of harmful activities decreased, assessing economic costs due to the damages as well finding perpetrators create problems.

\section{Preserving biodiversity}

The concept of SFM encompasses the protection of forest ecosystems. Forests with productive, economic function constitute $47.48 \%$ of all forests in Poland (data from 2010), whereas those fulfilling protective functions comprise $21 \%$ forests with the aim of protecting water and $4.6 \%$ forests protecting soil. Forests existing within urban and around urban areas (non-productive) constitute $9.0 \%$ of the total forest cover in Poland, whereas $1.25 \%$ of forests are excluded from harvesting as nature reserves and $4.7 \%$ perform other protective functions (e.g. environmentally valuable areas, animal sanctuaries, permanent research areas, reproductive areas, health resort forests). Additionally, $1.87 \%$ of forests remain non-productive for military reasons. There exist considerable differences between public and private forests: in $2010,46.6 \%$ of forests managed by the State Forests were marked out as protective, while the function in this scope was declared for $29.4 \%$ of forests owned by communities and $3.9 \%$ of those privately owned (GUS 2011b).

The structure of the system of protected areas which include forested lands is summarized in tab. 6 . There are also designated other protected elements such as ecological sites, nature monuments, protective zones and selected seed stands. Numerous rare forest plant and animal species are protected under the law. Other protected forest areas are established in line with international agreements, e.g. Man and Biosphere Baltic Sea Protected Area, UNESCO World Heritage Sites and NATURA 2000 areas.

NATURA 2000 areas were established within already protected areas such as national and landscape parks or nature reserves or else were newly designated. Unfortunately, information about the whole share of forests in NATURA 2000 areas is not available. Exact, updated figures exist only for the forests managed by the State Forests. In 2010, in Poland there were 144 areas of special habitat protection and 823 areas of special 
bird protection. Within state owned forests, about $40 \%$ of the area is protected by the Natura 2000 network (GUS 2011a; The State Forests in figures 2011).

Tab. 6. Nature protection in Poland in 2010

\begin{tabular}{|c|c|c|c|c|}
\hline Protected areas & $\begin{array}{l}\dot{\bar{D}} \\
\bar{\Xi} \\
\text { 艺 }\end{array}$ & 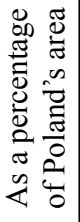 & 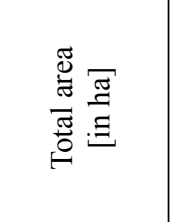 & 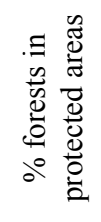 \\
\hline \multicolumn{5}{|c|}{ National system of protected areas } \\
\hline National parks & 23 & 1.0 & $314,474.5$ & 61.9 \\
\hline Natural reserves & 1463 & 0.5 & $164,202.1$ & 60.4 \\
\hline Landscape parks & 121 & 8.1 & $2,529,022.0$ & 50.15 \\
\hline $\begin{array}{l}\text { Protected landscape } \\
\text { areas }\end{array}$ & 386 & 22.3 & $6,990,047.7$ & 31.5 \\
\hline Other* & 7350 & 0.5 & $145,378.3$ & $53.6^{* * *}$ \\
\hline \multicolumn{5}{|c|}{ Natura $2000^{* *}$} \\
\hline $\begin{array}{l}\text { Areas of special habitat } \\
\text { protection }\end{array}$ & 823 & 11 & $3,791,720$ & $21.4^{* * *}$ \\
\hline $\begin{array}{l}\text { Areas of special bird } \\
\text { protection }\end{array}$ & 144 & 16 & $5,570,912$ & $29.2^{* * *}$ \\
\hline
\end{tabular}

* documentation sites, ecological arable lands (utility) and landscape-nature complexes; ${ }^{* *}$ without areas lying out in the sea; ${ }^{* * *}$ data only for the State Forests.

Source: GUS 2011b; , The State Forests in figures 2011.

In Polish forests, safeguarding of biological diversity is connected with decreasing monotypisation (one-species tree stands), pinetisation (introduction of coniferous trees, especially Pinus sylvestris) and neophytisation (introduction of foreign species). Negative effects of inappropriate forest management were due to focusing forest management on timber production in the past. In Poland, the process of reconstruction of tree stands has taken many years. Since 1991 monotypic forests have not been planted. Moreover, deformed tree stands have been rebuilt progressively for the last dozens of years (Koziol and Matras 2011). This has allowed to reduce pinetisation. As mentioned above, the pine has always been the most welcome species in the wood industry. Hence, coniferous monotypic forests have been before laid out. Pines used to be planted within the natural habitats of other tree species. Nowadays, reconstruction of tree stands allows to increase the share of broadleaved trees in the total forest area, keeping in line with natural conditions of forest habitats (GUS 2011b). However, the share of tree stands not compatible with forest type sites is still notable $(19 \%$ of the total forest area) (Koziol and Matras 2011). In the case of Polish forests, the share of alien tree species is not higher than $0.5 \%$ of the total forest area and none of them is treated as an invasive species (Kozioł and Matras 2011).

\section{FOREST OWNERSHIP AND ITS INFLUENCE ON FOREST ESTATE AND MANAGEMENT}

The majority of Poland's forests is state owned (tab. 1). The share of public forests in Poland exceeds that average for 27 countries of the European Union (approximately $40 \%$ of the total forest area in 2005) (Forestry in the EU and the world - a statistical portrait. 2011). The ownership structure as such secures state responsibility for coherent national forest policy, open access to forests for society, and consent for exploitation of nonwood forest products in addition to assurance of protective forest functions. For instance, in 2005, 35.5\% of Poland's total forest area was designated as forests with protective functions, whereas those in the EU countries (27) constituted 12.7\% (Eurostat 2012).

Owing to the high share of state owned forests, Poland has avoided in great measure the problem experienced by other European countries that is forest fragmentation. In Poland, forest fragmentation occurs when large continuous forests are divided into smaller blocks due to road-building (Environmental statistics and accounts in Europe 2010).

\section{SOCIAL FUNCTIONS OF FORESTS}

Social functions of forests are difficult to define and measure, but they are commonly connected with the so-called social services: recreation, tourism, education and various cultural aspects (e.g. tradition).

The State Forests puts a lot of efforts into rising public awareness based on recreational and educational infrastructure, including: parks and arboreta (17), centres of ecological education (over 20), educational rooms (50), points (318) and paths (over 150), the so-called green schools and Promotional Forest Complexes. Ad- 
ditionally, ecological NGOs, managements of municipal forests, national and landscape parks have their own educational and promotion activities, and they most often collaborate with the State Forests. Besides, kilometres of tourist routes have been traced and equipped in forests by the best known tourism organisation in Poland - PTTK (Polish Tourist Country-Lovers Society).

The Promotional Forest Complexes (PFCs) are special areas designated in Polish forests to demonstrate different forest habitats, changeability of forest ecosystems and their multifunctional role. PFCs also promote FSM, support scientific research (including testing new technologies in forestry) and public education. PFCs are also acknowledged as a forum of co-operation between forest administration, local authorities and communities. In 2010, in Poland, there existed $19 \mathrm{PFCs}^{8}$ in various regions with the total area of over 1 million ha, that was about $14 \%$ of forests managed by the State Forests (Blichtarska et al. 2012).

\section{Conclusions}

Sustainable forest management concerns the use of forest resources that assures safeguarding and enhancement of forest functions. Sustainable forestry encompasses timber production biodiversity protection and fulfillment of a variety of human needs. Achieving balance between these aspects is very difficult, especially when human needs are constantly growing. Forests, as ecosystems, provide people not only for material goods such as timber or fruits and herbal plants or else animals but also for non-material benefits connected with rest recreation and culture. Forest are indispensable to maintain energy flows and matter circulation in the world. Consequently, proper management of forest resources is imperative.

The analysis the SFM achievements in Poland and general comparison with those in the $\mathrm{EU}^{9}$ allowed the following conclusions:

- the high share of state owned forests in Poland seems to guarantee SFM implementation, even though not all activities undertaken are fully successful;

\footnotetext{
${ }^{8}$ In 2013 there were already 25 PFCs.

9 Comparisn was not possible in all presented categiories by reason of lack data for EU-27.
}

- the forest cover and stand age structure are increasing: Poland has avoided the problem of deforestation and the amount of forest resources has magnified, however it is yet less than the EU's average;

- tree stands are reconstructed towards adjustment to suitable habitats;

- forest health and vitality are maintained at a good level; one of the main problems which is tree defoliation has been successfully overcome during last 10 years; based on criteria used it can be stated that the condition of Polish forests is in the main better than that in the EU's forests;

- Poland's forest biodiversity is well protected;

- productive and protective functions of Poland's forests are quite well-balanced; in fact the share of protective forests is the biggest in the EU;

- Poland is one of the important wood producers in Europe: timber harvesting is above the average for Europe (and has an increasing tendency); viable exploitation of non-timber products has been also achieved.

The results of the analyses carried out justify the conclusion that forestry in Poland has improved towards implementation of SFM. However, many factors, along with a number of conceptual and practical problems still remain a challenge to face by Polish forestry on its way to sustainability.

\section{References}

Bartelmus P. 2003. Dematerialization and capital maintenance: two sides of the sustainability coin. Ecological Economics, 46, 61-81.

Baycheva T., Inhaizer H., Lier M., Prins K., Wolfslehner B. 2013. Implementing criteria and indicators for sustainable forest management in Europe, report. available at: http://www.ci-sfm.org/report. html. Accessed: 10.01.2014.

Bernadzki E. 2006. Forest and forestry in European Union countries. Centrum Informacyjne Lasów Państwowych, Warsaw.

Blichtarska M., Angelstam P., Elbakidze M., Axelsson R., Skorupski M., Węgiel A. 2012. The Polish Promotional Forest Complexes: Objectives, implementation and outocomes towards sustainable forest management? Forest Policy and Economics, 23, 28-39. 
$\operatorname{COM}(2006) 302$ final: Communication from the Commission to the Council and the European Parliament on an EU forest action plan \{SEC(2006) 748\}. 2006.

$\operatorname{COM}(2013) 659$ final: Communication from the Commission to the European Parliament, the Council the European Economic and Social Committee and the Committee of the Regions. A new EU Forest Strategy: for forests and the forest-based sector $\{$ SWD(2013)342 final $\}$ SSWD(2013) 343 final $\} .2013$.

Drozdowski S. 2008. Functional areas in forestry - the theoretical background. Studia i Materiaty Centrum Edukacji Przyrodniczo-Leśnej, 3 (19), 11-20 [in Polish].Environmental statistics and accounts in Europe. 2010. Eurostat, Statistical Books.

European Council. 1998. Council Resolution of 15 December 1998 on a forestry strategy for the European Union. Official Journal of the European Communities, 1999/C 56/01.

Eurostat Newsrelease 85. 2011. http://epp.eurostat. ec.europa.eu. Accessed: 23.11.2012.

Forestry in the EU and the world - a statistical portrait. 2011. Eurostat, Statistical Books.

Forests in Poland 2011. Centrum Informacyjne Lasów Państwowych, Warsaw.

Global Forest Resources Assessment 2005. Progress towards sustainable forest management. FAO Forestry Paper, 147, 1- 350.

Global Forest Resources Assessment 2010. Main report. FAO Forestry Paper, 163, 1-378.

GUS. 2008a. Environment 2008. Ochrona środowiska 2008. Zakład Wydawnictw Statystycznych, Warsaw.

GUS. 2008b. Forestry 2008. Zakład Wydawnictw Statystycznych, Warsaw.

GUS. 2009. Forestry 2009. Zakład Wydawnictw Statystycznych, Warsaw.

GUS. 2010. Forestry 2010. Zakład Wydawnictw Statystycznych, Warsaw.

GUS. 2011a. Environment 2011. Ochrona środowiska 2011. Zakład Wydawnictw Statystycznych, Warsaw.

GUS. 2011b. Forestry 2011. Zakład Wydawnictw Statystycznych, Warsaw.

GUS. 2012. Forestry 2012. Zakład Wydawnictw Statystycznych, Warsaw.
Gustavsson R., Hermy M., Konijnendijk C., SteidleSchwahn A. 2005. Management of urban woodlands and parks - Searching for Creative and Sustainable Concepts. In: Urban Forests and Trees (eds.: C.C. Konijnendijk, K. Nilsson, Th.B. Randrup, J. Schipperijn), Springer, 369-397.

Keiner M. 2004. Re-emphasizing sustainable development - the concept of evolutionability. Environment, Development and Sustainability, 6, 379-392.

Kozioł C., Matras J. 2011. Home Report on forests genetic resources. Available at: http://www.lbg. jgora.pl/Raport_FAO.pdf. Accessed: 27.11.2012 [in Polish].

Meyerhof J., Liebe U., Harje V. 2009. Benefits of biodiversity enhancement of nature-oriented silviculture: Evidence from two choice experiments in Germany. Journal of Forest Economics, 15, 37-58.

Panagopoulos T. 2009. Linking forestry, sustainability and aesthetics. Ecological Economics, 68, 2485-2489.

Regulation 11 of the State Forests' General Director. 1995.

Regulation 11A of the State Forests' General Director. 1999.

Report on the forests conditions in Poland 2010. 2011. Centrum Informacyjne Lasów Państwowych, Warsaw. Available at: www.lasy.gov.pl. Accessed: 12.11.2012.

Report on the forests conditions in Poland 2011. 2012. Centrum Informacyjne Lasów Państwowych, Warsaw. Available at: www.lasy.gov.pl. Accessed: 12.11.2012.

Report of the UN Conference on environment and development. 1992. Annex III, A/CONF.151/26.

State of Europe's Forests. 2011. UNECE, FAO.

Szaro C.R., Langor D., Yapi A.M. 2000. Sustainable forest management in the developing world: Science challenges and contributions. Landscape and Urban Planning, 47, 135-142.

The State Forests in figures. 2011. Centrum Informacyjne Lasów Państwowych, Warsaw.

Wijewardana D. 2008. Criteria and indicators for sustainable oforest management: The road travelled and the way ahead. Ecological Indicators, 8, $115-122$. 